\title{
The Effect of Social Networking Sites to the Lifestyles of Teachers and Students in Higher Educational Institutions
}

\author{
Seguya Asad ${ }^{1}$, Md. Abdullah-Al-Mamun ${ }^{2}$, Che Kum Clement ${ }^{3}$ \\ Department of Technical and Vocational Education, Islamic University of \\ Technology \\ E-mail: sgyasad@yahoo.co.uk ${ }^{1}$, abmamun@iut-dhaka.edu $^{2}$, chekum@iut- \\ dhaka.edu $^{3}$
}

\begin{abstract}
With the creation of Social Networking Sites, colleges and universities across the globe have been playing catch-up with students. This new technology carries much weight as a new medium for students to build social connections and grow as members of their institutions [1]. With the aim of exploring the effect of social networking sites to the lifestyles of teachers and students in higher educational institutions, this research was conducted at four private universities in Bangladesh and one university in Uganda. A sample of one hundred teachers and one hundred students was respectively selected from four private universities in Bangladesh and one university in Uganda. Both qualitative and quantitative methods were applied during data analysis. The results indicated that social networking sites had several impacts on the lifestyle of students and teachers with the positive effects outweighing the negative effects. The findings confirmed that students can formulate group discussions so as to exchange their ideas, communicate to their teachers and appeal to their friends about assignments. Teachers share course related materials with their students, enables research work, creates student groups to collaborate on projects and communicate with their fellow teachers from other universities. So the principal conclusion was that the use of social networking sites should be incorporated into teachers' and students' lifestyles as its beneficial nature takes over its adverse side.
\end{abstract}

Keywords: Social Networking Sites, Academic Lifestyle, Higher Educational Institutions 


\section{Introduction}

The critical role of interaction in learning is reinforced by the addition of Social Networking Sites (SNSs) to the academic community. Therefore, the addition of social network augments the learning community rather than providing an alternative to it, resulting in overall enhancement of the learning environment [2]. Social Networking Sites can be defined as: Sites that allow individuals to (i) construct a public or semi-public profile within a bounded system, (ii) articulate a list of other users with whom they share a connection, and (iii) view and traverse their list of connections with those made by others within the system. The nature of these connections may vary from site to site [3].

Every technological innovation has been a topic of debate and center of researchers' attention and same is the case with the development of SNSs. Various researchers have conducted studies to pinpoint the several impacts of these sites on their users and findings suggested both bright and dark aspects. It has been found that excessive usage causes many psychological, physical, interpersonal and educational problems to users [4]. Numerous studies have also been conducted to delineate the impact of SNSs on young generation and students [5]. This current study specifically aims at exploring the effects of SNSs on the lifestyles of teachers and students in higher educational institutions so would be a value addition to this research area.

\subsection{Academic Benefits of Social Networking Sites}

Social networking sites have become increasingly integrated into the way many people today act, think, and relate to each other. Social networking has a multitude of implications in the field of education and these impacts on students, educators, administrators, and parents are similar [6].

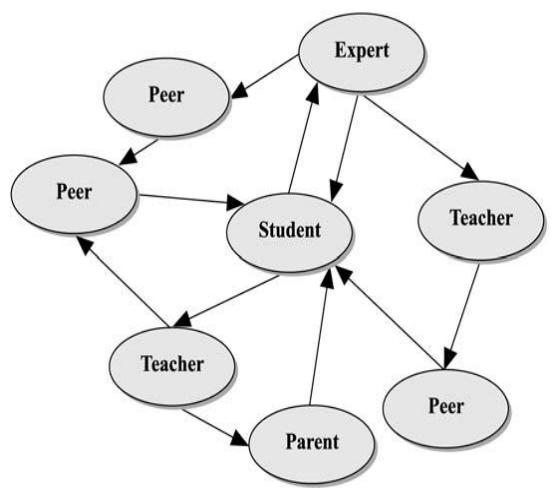

Fig1: Multi-directional communication enabled by SNSs; Source: [26]

This figure shows that different users have multi-directional communication with multiple parties. The communication patterns enabled by social networking 
technologies mirror the exact process many educators seek to support in selfdirected learning based on constructivist, connectivist, and constructionist [7] learning theories. These communication mechanisms are empowering and engaging to learners, and contribute to the ongoing evolution of human society. It is important to acknowledge that credibility and expertise in social networking comes from the extent of involvement in the network, including the amount of participation, frequency, and the usefulness of the information provided. Teachers and students in virtual worlds must gain benefits [8] through ongoing participation in networks to develop their credibility as a network member.

Bishop, Dubord, Hansen, \& Webster [9] reiterate that Facebook's online community meets the requirements set forth by Chickering et al [10] for an environment that promotes student development by providing regular interaction between students and opportunities for collaboration with people from diverse backgrounds and that serves as a social reference group. These affordances for collaborative networking and persistent interactions present Facebook as a vantage point for unraveling lecturer-student power relations, if academics support was rendered via this site [11].

SNSs platforms allow for the extension of learning discussion outside the formal classroom setting, therefore promoting deeper learning as young people not only engage with the material for longer but are more likely to relate to it and incorporate it into their everyday lives [12]. Another studies conducted on the use of hand held devices to deliver workplace learning demonstrated that regular accessibility means young people can access resources in a way that is both convenient and relevant to them. This in turn translates into increased levels of implementation into work practice [13]. Many researchers found a positive association between the use of SNSs and academic performance of the student users. Students, who used SNSs scored higher on reading skills test and had higher grades as well. Also it has been found that Facebook usage is helpful for cure in case of some psychological problems including low life-satisfaction and low self-esteem [14]. SNSs also provide a rich mean of interaction between teachers and students as stated by Roblyer et al. [15].

Ginsburg-Block et al. [16] argues that most participant learning experience on SNSs is associated with social learning. As a consequence, social learning outcomes constitute the majority of learning outcomes. Cognitively, they learn how to creatively solve problems via information searching and online friends' help. Affectively, they feel free to express and present themselves, share feeling with others, and gain more confidence from champions. Finally, they improve their social skill and collaborative skill, and also more willing to share their own knowledge with peers. He continues that these are beneficial for their well-being development such as self-esteem and satisfaction with life. Although the students 
do not explicate the academic learning outcomes from online social networking, it cannot deny the impact of online social networking on academic learning outcomes [16]. For junior students, they might first experience social learning and social integration into the university (e.g., learning the culture or subculture of the university and interacting with peers), and then feel more comfortable interacting with faculty to reach a higher level of academic integration and learning outcomes. Thus, students' academic learning outcomes could increase when their social learning outcomes were heightened.

\subsection{Arguments against Social Networking Sites in Education}

Leach [17] points out that teacher ought to exploit their pupils' existing ICT knowledge and use the tools to which pupils are already accustomed. However, Mazer et al. [18] suggested that certain affordances of ICT, such as SNSs, can be a potential hazard for teachers as some applications allows users to communicate and the content can lead to discrediting or defamatory messages. In addition, others point out that SNSs can be used for plagiarism, cheating, harassment and other types of academic and social misconduct [19]. Overall, a picture of risk and danger emerges. As Selwyn [20] notes, SNSs can place children at risk of harming themselves and others.

SNSs discourage Face-to-Face Communication. Some educators are concerned that while real-time digital stream may create a safe harbor for students who are uncomfortable expressing themselves, students are missing valuable lessons in real-life social skills. Students may find themselves at a disadvantage during college admission or job interviews when they need to command attention and deliver a coherent message. At social gatherings and in personal relationships, they need to be able to effectively express themselves and connect with others [21].

Spending much time on SNSs causes an effect on health of individuals. This is because the more time spent while browsing these social networks can affect the way the genes operate within the human body, and weakens the immune and hormone levels, and function of arteries. In addition, it also has an impact on mental health. Moreover, the use of SNSs in education can cause lack of motivation towards learning and can be boring sitting in front of computer for a long time, especially if the scientific material presented is free of audio and visual effects that will attract learner towards learning.

\subsection{Social Networking Sites in the Teachers and Students Social Lifestyle}

SNSs were integrated thoroughly into teacher and student life because of high technology adoption rate and of availability of computers, network etc. but more 
importantly it was integrated because teacher and student life lends themselves to non-orderly social behavior. Teachers and students need reminders for events, incentives for social gatherings and facilitators for ad-hoc meetings, particularly very sporadic ones. Despite being busy, they are also highly social and SNSs helps them to achieve that [22].

SNSs are used to support offline ties and connections. According to the previous studies, it was found that SNS can be used to leverage other means of communication when lightweight interaction is preferred. Similarly to the way in which text messages were often used in cases where phone calls would not necessarily have been placed before [23]. This does not mean that the communication is insignificant as Nathan also describes in his research experience [24].

University students are at a stage in life where their social life is pivotal to their quality of life. It is also a time where friendships are made, maintained, broken and perhaps revived. Interestingly, students use SNSs to not only plan socialization with friends but also to overcome their shyness over contacting peripheral friends directly [22]. As Nathan also describes, students often have a set of five or six close friends, but these friends also had similar sets of close friends that did not necessarily overlap, making friends of friends acquaintances or peripheral [24]. As Boyd [3] has pointed out previously in connection with other online social networks that friendship is a flexible notion and peripheral friendships can grow into closer friendships and Facebook, in this sense, was a practical facilitator for precisely this process [3].

\section{Methodology}

This study was conducted with the objective of exploring the effects of social networking sites on the lifestyles of teachers and students in higher educational institutions. Students are viewed as the highest customer segment and the most vivid users of SNSs. A sample of one hundred teachers and one hundred students was selected from different private universities both in Bangladesh and Uganda. The universities selected were: Islamic University of Technology (IUT), Asian University, Ahsanullah University of Science \& Technology, International Islamic University of Chittagong (IIUC) from Bangladesh and Islamic University in Uganda (IUIU) from Uganda. Therefore, data was supposed to be collected from 200 respondents from these five selected private universities. Random sampling was used to select both the teachers and students form each university.

Out of the total 100 distributed questionnaires to the teachers, $84 \%$ fully completed questionnaires were returned. On the other hand, a $100 \%$ response was received from the 100 distributed questionnaires from the students' side. Two 
structured questionnaires were developed in order to collect the data from the teachers and students respectively. These questionnaires involved both restricted and open ended questions with each questionnaire having three sections. Both qualitative and quantitative methods were applied during data analysis. Furthermore, weighted average and chi-square were the techniques used to analyze the data collected.

\section{Analysis of the Data and Findings}

Figure 2 below shows the findings on several factors related to internet and SNSs usage. Students were asked where they accessed the internet. Majority of them (52\%) responded that they accessed the internet from their hostels, $43 \%$ from computer laboratory, $8 \%$ from their classes and 3\% from the library. Some students accessed the internet from more than one place such as classes and hostels, hostels and computer laboratory.

When respondents were asked which SNSs they used, majority (90\%) of them used Facebook, followed by (15\%) Twitter, (9\%) Google Plus, whereas others $(6 \%)$ indicated that they used other SNSs. Students used different devices to access the internet. This study shows that $87 \%$ used computers, $22 \%$ used their mobile phones and $2 \%$ used other devices. When responses were taken about the time being spent on SNSs, majority $(47 \%)$ of the students indicated that they logged in once in a day, $36 \%$ spent $2-5$ times a day, $10 \%$ spent a couple of hours and only $7 \%$ were always logged on.

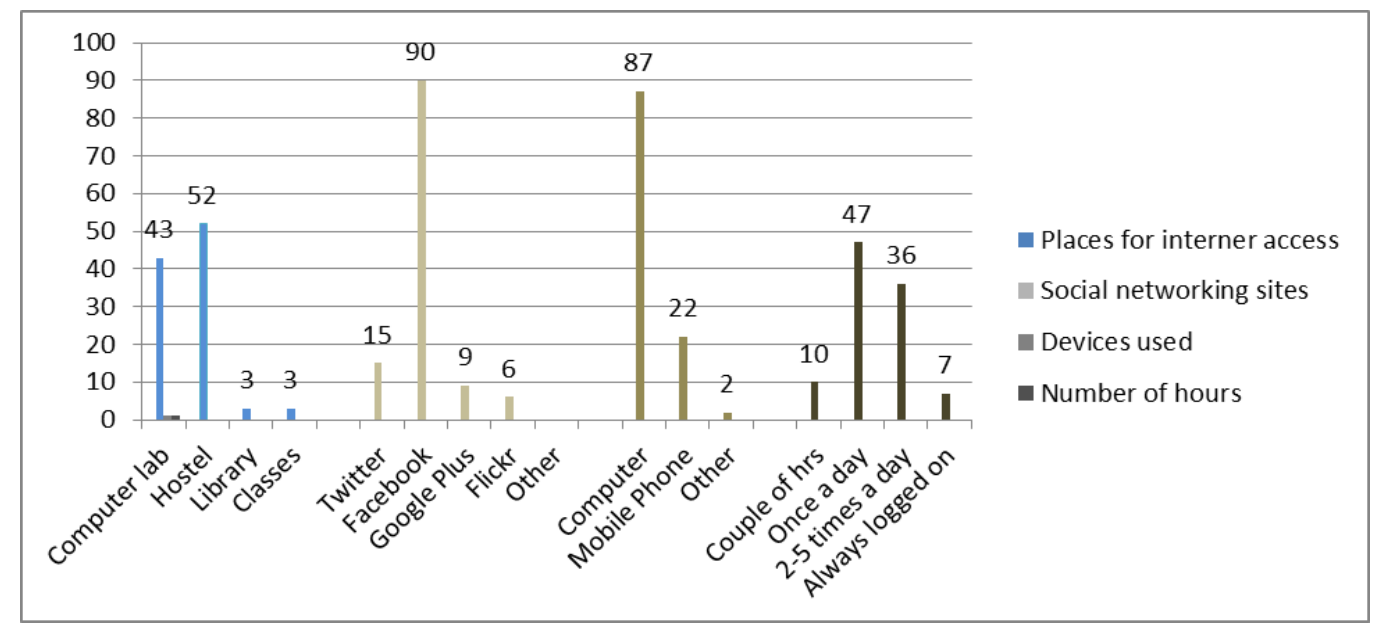

Fig 2: Students' experience with social networking sites and internet usage

Regarding the effects of social networking sites responses obtained from the students which are depicted in the following table 1 . The table indicates majority of the students agreed that social networking sites helped them to receive information about homework, materials, projects, resources etc. According to 
previous research, Heavin (2007) and Pearson (2009) found that a secondary school teacher was reported to have successfully used SNSs in reminding students of upcoming homework deadlines. These findings continue to show that students used SNSs for communicating with their teachers outside school hours. This claim is supported by Trzeszkowski (2007) who suggested that her profile on Facebook has allowed her to establish deeper relationships with and understandings of her students because she can communicate with them beyond the four walls of the classroom.

Table 1: Effects of social networking sites to students

\begin{tabular}{|c|c|c|}
\hline Statement & WA & $\begin{array}{l}\text { Chi Square } \\
\text { value }\end{array}$ \\
\hline \multicolumn{3}{|l|}{ Positive Effects } \\
\hline $\begin{array}{l}\text { Sharing homework, information of study materials, projects, } \\
\text { resources or ideas }\end{array}$ & 3.87 & .000 \\
\hline Communicating to teachers & 3.55 & .000 \\
\hline General group discussion and exchanging ideas & 3.51 & .000 \\
\hline Assignment preparation and argument & 3.58 & .000 \\
\hline $\begin{array}{l}\text { Communication among students and their instructors, } \\
\text { following announcements about classes and courses }\end{array}$ & 3.53 & .000 \\
\hline \multicolumn{3}{|l|}{ Negative Effects } \\
\hline $\begin{array}{l}\text { Paying more attention towards SNS than utilizing this time } \\
\text { for their studies }\end{array}$ & 3.85 & .000 \\
\hline Poor performance (lower grades) & 3.17 & .001 \\
\hline Failure to meet study targets & 2.94 & .002 \\
\hline Missing classes due to SNS & 2.66 & .368 \\
\hline Reduction in face to face human contact & 3.36 & .001 \\
\hline
\end{tabular}

While responding to query whether they used SNSs to communicate with each other and to their instructors, follow announcements about classes and courses, majority of the students admitted that they used SNSs for that purpose as clearly indicated by the weighted average. The chi square values are less than the critical value (0.05) which indicates that the null hypotheses are rejected and the research hypothesis is accepted. So the responses on all the statements are statistically significant.

Regarding the negative effects of using Social Networking sites, research findings indicated that students get lesser time for their study due to over usage of SNSs. According to Karpinski et al (2009), he stated that Facebook users devoted lesser time to their studies than the nonusers did and subsequently had lower GPAs. Based on the findings of this study, majority of the students agreed that they paid more attention towards SNS than utilizing this time for their studies. They went ahead to show that as a result of this, they scored lower grades. Hameed et al, (2008) stated that SNS lead to miscommunication in that it does not afford the 
student with the same opportunities of explanation and clarification that occur in face-to-face interaction. This is in line with the findings of this study where students affirmed that the use of SNSs reduces their opportunities of face-to-face contact with their teachers. The students were further unable to give opinions on the claim whether their frequent usage of SNSs fails them to meet their study targets as well as missing their classes. In most cases, the chi square values are less than the critical value (0.05) except for 'missing classes due to SNS' which clarifies that the null hypothesis is accepted and the research hypothesis is rejected. This shows that the responses on most of the statements are statistically significant.

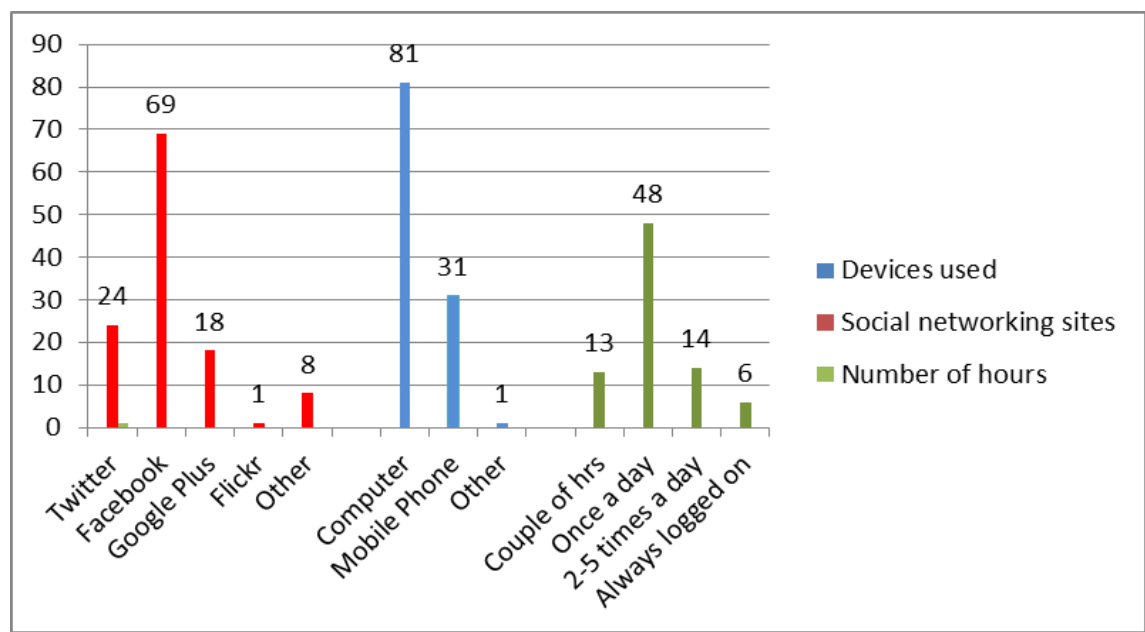

Fig 3: Teachers' experience with social networking sites and internet usage

Figure 3 shows the findings on several factors related to internet and SNSs usage. Teachers were asked which SNSs they used, majority $(82.1 \%)$ of them used Facebook, followed by (28.6\%) Twitter, (21.4\%) Google Plus, others $(9.5 \%)$ indicated that they used other SNSs whereas the least number $(1.2 \%)$ used Flickr. Teachers used different devices to access the internet. This study shows that 96.4\% used computers, $36.9 \%$ used their mobile phones and $1.4 \%$ used other devices. When responses were taken about the time being spent on SNSs, majority $(57.1 \%)$ of the teachers indicated that they logged in once in a day, $16.7 \%$ spent 25 times a day, $15.5 \%$ spent a couple of hours and only $7.1 \%$ were always logged on.

The findings regarding the positive effects show that teachers utilize the opportunity of social networking sites to share information and other course related materials with their students which is depicted in the table 5. Referring to previous research, Yan (2008) confirmed that online learning communities give teachers and students the ability to personalize and share their content. Carter et al, 2008 in his research work pointed out some examples of teachers incorporating SNSs directly into their pedagogical practice which concluded that there may be 
benefits in carefully considered use of social network media. When responding to this query, majority of the teachers indicated that with the use of SNSs, they managed to learn how to incorporate it into teaching.

Table 2: Effects of social networking sites to teachers

\begin{tabular}{|l|c|c|}
\hline Statement & WA & $\begin{array}{c}\text { Chi Square } \\
\text { value }\end{array}$ \\
\hline Positive Effects & & \\
\hline Share information and resources with students & 3.76 & .000 \\
\hline $\begin{array}{l}\text { Learn how social networking can be incorporated into } \\
\text { teaching }\end{array}$ & 3.40 & .000 \\
\hline Creates student groups to collaborate on projects & 3.56 & .000 \\
\hline $\begin{array}{l}\text { Increases teachers availability to students outside school } \\
\text { hours }\end{array}$ & 3.25 & .000 \\
\hline $\begin{array}{l}\text { Enables research through the exchange of different } \\
\text { materials }\end{array}$ & 3.52 & .000 \\
\hline Negative Effects & & .002 \\
\hline $\begin{array}{l}\text { Devotes little time to attend to students class related } \\
\text { problems }\end{array}$ & 3.09 & .002 \\
\hline Reduction in face-to-face human contact due to SNS & 3.53 & .018 \\
\hline $\begin{array}{l}\text { Reducing the time of doing research to improve on your } \\
\text { profession }\end{array}$ & 2.79 & .000 \\
\hline Affects profession reputation and career & 2.19 & .000 \\
\hline Causes stress and affects your health & 2.86 & .001 \\
\hline
\end{tabular}

According to the present findings, majority of the teachers showed that they used SNSs to create student groups so as to collaborate in projects and to send messages to students about their marks or work as cited by Heavin (2007). Also Pearson (2009) in his work indicated that he has successfully used SNSs such as Twitter and Facebook, for a variety of reasons including reminding students of upcoming homework deadlines, marks etc. Teacher's opportunities of conducting their research work are improved since SNSs permit the exchange of different materials and ideas. Alexander (2006) described the value of social networking tools such as social bookmarking for collaborative information discovery and writing. The responses in all the cases are statistically significant based on the chi square values which are less than 0.05 . So we reject the null hypothesis and we accept the research hypothesis.

On the contrary, it was found that teachers devoted little time to attend to students' class related problems. According to the research conducted by Greenfield et al, (2008), SNSs as well as other new forms of communication technology are concerns to many school professionals because of the level of distraction they create within the school. The study continued to show that teachers were unable to give their opinions whether SNSs reduce their time of doing research so as to improve on their professions and careers, causes stress and affects their brain etc. Furthermore, teachers disagreed with the claim that their 
usage of SNSs affects their profession and carrier. This indicated that their profession and career is affected by other factors but not SNSs. In all the cases, the chi square values are less than the critical value of 0.05 . Therefore, it can be concluded that the responses on all the statements were statistically significant.

\section{Conclusion}

Social networking sites are gaining a lot of popularity these days with almost all the educators and educated youth using one or the other such site. These have played a crucial role in bridging boundaries, crossing the seas and enabling them to communicate on a common platform [25]. The aim of this study was to investigate the effects that social networking sites have to the lifestyles of teachers and students in higher educational institutions. The findings show that most of the students usually spend little time on their social networking sites by logging in once a day. Majority of them use Facebook as their favorite SNS and mostly access it on their computers while in their hostels. It can be clearly seen that students devote little time to these SNSs. The findings continue to show that students use SNSs for academic and non-academic purposes but with academic purposes outweighing the non-academic. Students can formulate group discussions so as to exchange their ideas, share course related materials with their colleagues communicate to their teachers, appeal to their friends about assignments etc. However, there are some drawbacks that SNSs come with. Such drawbacks include spending a lot of valuable time on SNSs which results into poor performance, paying more attention towards SNSs than utilizing this time for their studies, reduction in face to face contact with their teachers, failure to meet their study targets etc. Their responses indicate that SNSs have a lot of positive influence on their lifestyle as compared to its negative side.

However, educators are also among the vivid users of SNSs. According to the findings of this research, majority of the teachers prefer to use Facebook than any other SNSs. They mostly login once a day and they get access to the internet while using their computers. Teachers have integrated social networking sites into their teaching methods. They use SNSs to share course related materials with their students, communicate to their students regarding their coursework's, assignments or any upcoming event, communicate with their fellow teachers from other universities something that has enabled them to improve on their research hence improving their careers. Much as social networking sites have been so beneficial to the teachers, to a lesser extent, they have also caused some drawbacks. Considering the findings of this study, teachers spend a lot of valuable time on SNSs while reading and answering unnecessary postings thereby devoting little time to attend to student class related problems, reduction in face to face contact with their students, causes stress and affects their health etc. Therefore this 
research study suggests that teachers as well as students should continue to use SNSs so as to exploit more benefits that are associated with them.

\section{Recommendation}

Due to the time constraints, the researcher could not conduct in depth study on this subject. To this regard he proposes that further in depth additional research should be conducted on the effects of social networking to the teachers and students lifestyles in higher educational institutions. This study has provided some information on how the social networking sites benefit the students and teachers as well as the drawbacks it causes to them. Further investigations on whether social networking sites positively or negatively affect teachers and students should be done in the following areas: (a) How to fully integrate social networking sites into teaching-learning, (b) How to minimize or eliminate the problems caused by social networking sites to students and teachers, $(c)$ Identify measures on how to control students and teachers over usage of social networking sites and $(d)$ How to motivate the teachers who are still resistant to this new technology (social networking sites).

\section{Acknowledgements}

We thank to Islamic University of Technology, for supporting us in conducting this research. In addition, we are grateful to Mr. Mokhter Ahmed, Mr. Shahed Harun, Mr. Jubaid Abdul Qauiyum and Mr. Shoeb Shahriar for the considerable help throughout this study.

\section{References}

[1] Boogart, M. R. V., "Uncovering The Social Impacts of Facebook on a College Campus", Master's Thesis, University of Wisconsin, Madison, 2006. http://krex.k state.edu/dspace/bitstream/2097/181/4/MatthewVandenBoogart2006.pdf, Accessed 08 August, 2012

[2] Network.Ed., "Teaching and Learning with Social Networks: Advantages and Disadvantages", 2012, http: //www.josepicardo.com/tag/case/, Accessed 29 July, 2012

[3] Boyd, d. Friends, "Friendsters, and MySpace Top 8: Writing Community Into Being on Social Network Sites", 2006. http://www.danah.org/papers/FriendsFriendsterTop8.pdf, Accessed 11 August, 2012 
[4] Suhail, K, \& Bargees, Z. "Effects of Excessive Internet Use on Undergraduate Students in Pakistan", CyberPhsychology \& Behavior, Vol 9(3), (2006), pp.297-307

[5] Ahmed, I \& Qazi, F. T., "A look out for academic impacts of Social networking sites (SNSs): A student based perspective", 2011 http://www.academicjournals.org/AJBM/PDF/pdf2011/18June/Ahmed\%20a nd\%20Qazi.pdf, Accessed 8 August, 2012

[6] Wikia., "Social networking in education wiki", 2012, http://socialnetworkingeducation.wikia.com/wiki/Social_Networking_in_Ed ucation_Wiki, Accessed 8 August 2012

[7] Harel, I. \& Papert, S., "Situating Constructionism \& Constructionism", Ablex Publishing Corporation, New York, 1991

[8] Castronova, E., "Synthetic Worlds: The Business and Culture of Online Games". University of Chicago Press, Chicago, 2006

[9] Bishop, R. J., Dubord, M., Hansen, E., \& Webster, K., "Acknowledging a campus.community: the facebook and diversity college", 2010, http://studentaffairs.com/vcs/2006entries/EasternMichiganUniversity.ppt, Accessed 11 August, 2012

[10] Chickering, M., \& Reisser, L., "Education and identity" (2nd ed.). San Francisco: Jossey Bass, 1993

[11] Rambe.P., "Exploring the impacts of social networking sites on academic relations in the university", 2011, http://independent.academia.edu, Accessed 8 August 2012.

[12] Notley, T. M., \& Tacchi, J. A., "Online Youth Networks: Researching the Experiences of Peripheral Young People in Using New Media Tools for Creative Participation \& Representation in 3CMedia", Journal of Community, Citizens and Third Sector Media and Communication, Vol 1(1), (2005), pp.73-81

[13] Huffstutler, S., Wyatt, T. H., \& Wright, C. P., "The Use of Handheld Technology in Nursing Education". Nurse Educator, Vol 27(6), (2002), pp.271-275

[14] Ellison, N. B., Steinfield, C., \& Lampe, C., "The benefits of Facebook "friends:" Social capital and college students' use of online social network site". Journal of Computer Mediated Communication, Vol 11(2), (2007), article 2, http://jcmc.indiana.edu/vol11/issue2/ellison.html, Accessed 12 August, 2012

[15] Roblyer, M. D., McDaniel, M., Webb, M., Hermann, J., \& Witty, J. V., "Findings on Facebook in higher education: A comparison of college faculty and student uses and perceptions of social networking sites". The Internet \& Higher Education, Vol 13(3), (2010), pp.134-140

[16] Ginsburg-Block, M. D., Rohrbeck, C. A., \& Fantuzzo, J. W., “A metaanalytic review of social, self-concept, and behavioral outcomes of peerassisted learning". Journal of Educational Psychology, Vol 98, (2006), pp.732-749 
[17] Leach, J., "Teaching, learning and the digital age”. In: B. Moon, A. Shelton Mayes, S. Hutchinson (eds.) Teaching, learning and the curriculum in secondary schools. London: RoutledgeFalmer, (2002), pp.142-164

[18] Mazer, J. P., Murphy, R. E., \& Simonds, C. J., 'I'll see you on Facebook: The Effects of Computer-Mediated Teacher Self-Disclosure on Student Motivation, Affective Learning, and Classroom Climate". Communication Education, Vol 56(1), (2007), pp.1-17

[19] Anderson, T., "Social Networking." In S. Mishra (Ed.), E-Learning: STRIDE Handbook Vol 8 (pp. 96-101). New Delhi, 2010.

[20] Selwyn, N., "The digital native: myth and reality". ASLIB, Vol 61(4), (2009), pp.364-379

[21] ITS., "Pros and cons of social media in the classroom, Information technology and services", 2012, http://ols.syr.edu/archives/category/socialmedia, Accessed 5 August, 2012

[22] Barkhuus, L, \& Tashiro, J., "Student Socialization in the Age of Facebook", 2010 http://citeseerx.ist.psu.edu/viewdoc/download?doi=10.1.1.178.5784\&rep=rep $1 \&$ type $=$ pdf, Accessed 8 August 2012

[23] Ling, R., "The Mobile Connections, Morgan Kaufmann Publishers", San Francisco, 2004.

[24] Nathan, R., "My Freshman Year. What a professor Learned by Becoming a Student", Cornell University Press, New York, 2005

[25] National Computer Board (NCB), "Guideline on social networks", 2011 http://www.gov.mu/portal/sites/cybersecurity/documents/Guideline\%20on\% 20Social\%20Networks.pdf, Accessed 8 August 2012

[26] Dawley, L. (2009). Social network knowledge construction: emerging virtual world pedagogy, http://www.emeraldinsight.com/journals.htm?articleid=1793740\&show=abst ract, Accessed 14 August 2012 